\title{
Statut Polskiego Towarzystwa Teologicznego
}

\section{Postanowienia ogólne}

Art. 1

Polskie Towarzystwo Teologiczne, zwane dalej: Towarzystwem, jest publicznym stowarzyszeniem wiernych w rozumieniu kodeksu prawa kanonicznego z 1983 r. oraz organizacją kościelną w rozumieniu ustawy z dnia 17 maja 1989 r. o stosunku Państwa do Kościoła Katolickiego w Rzeczypospolitej Polskiej (tekst jedn. Dz.U. z 2018 r. poz. 380).

Art. 2

1. Towarzystwo jest kościelną publiczną osobą prawną na podstawie dekretu Przewodniczącego Konferencji Episkopatu Polski z dnia 7 kwietnia $2004 \mathrm{r}$.

2. Towarzystwo posiada osobowość prawną nadaną rozporządzeniem Ministra Spraw Wewnętrznych i Administracji z dnia 12 lipca 2004 r. w sprawie nadania osobowości prawnej Polskiemu Towarzystwu Teologicznemu (Dz.U. Nr 167 poz. 1756).

3. Towarzystwo podlega nadzorowi Konferencji Episkopatu Polski, która na wniosek zarządu Towarzystwa mianuje asystenta kościelnego na 5-letnią kadencję z możliwością pełnienia tej funkcji przez kolejne kadencje za zgodą przełożonego, któremu podlega (kan. 317 § 1 KPK).

Art. 3

1. Siedzibą Towarzystwa jest miasto Kraków.

2. Patronem Towarzystwa jest św. Jan Kanty.

3. Terenem działalności Towarzystwa jest terytorium Rzeczypospolitej Polskiej.

4. Towarzystwo może być członkiem organizacji międzynarodowych, których cele są zbieżne z wymienionymi w art. 4 statutu. 


\section{Cele i środki}

Art. 4

Celem Towarzystwa jest:

1) prowadzenie badań naukowych w dziedzinie nauk teologicznych oraz badań interdyscyplinarnych w innych dziedzinach nauki, w szczególności w dziedzinie nauk humanistycznych, społecznych i sztuki;

2) działalność upowszechniająca naukę;

3) działalność edukacyjna;

4) działalność kulturalna;

5) działalność kultu religijnego.

\section{Art. 5}

Towarzystwo realizuje swoje cele w szczególności poprzez:

1) spotkania naukowe;

2) wyjazdy naukowe;

3) wydawanie publikacji naukowych lub popularnonaukowych;

4) projekty badawcze;

5) finansowanie badań naukowych;

6) przyznawanie nagród;

7) współpracę z towarzystwami naukowymi oraz z uczelniami i szkołami;

8) ustanawianie fundacji wspierających działalność Towarzystwa.

\section{Członkostwo}

Art. 6

Członkowsko w Towarzystwie jest zwyczajne, wspierające i honorowe.

Art. 7

1. Członkami zwyczajnymi mogą być katolicy posiadający wykształcenie wyższe w dziedzinie nauk teologicznych lub w innych dziedzinach nauki, w szczególności w dziedzinie nauk humanistycznych, społecznych i sztuki, którzy złożyli wniosek o przyjęcie do Towarzystwa.

2. Członkostwa w Towarzystwie nie mogą nabyć osoby, które publicznie odstąpiły od wiary katolickiej albo zerwały wspólnotę kościelną, 
albo podlegają ekskomunice nałożonej wyrokiem lub zadeklarowanej (kan. 316 § 1 KPK).

\section{Art. 8}

1. Członków przyjmuje zarząd na pierwszym posiedzeniu po złożeniu wniosku o przyjęcie do Towarzystwa.

2. Zarząd może odmówić przyjęcia do Towarzystwa, informując o tym wnioskodawcę w terminie do 14 dni od dnia pierwszego posiedzenia po złożeniu wniosku o przyjęcie do Towarzystwa.

\section{Art. 9}

Członek Towarzystwa ma prawo:

1) udziału w spotkaniach naukowych Towarzystwa;

2) korzystania biblioteki Towarzystwa;

3) udziału w walnym zebraniu;

4) wyborcze czynne i bierne do władz Towarzystwa.

\section{Art. 10}

Członek Towarzystwa ma obowiązek:

1) przestrzegania statutu i regulaminów Towarzystwa;

2) czynnego udziału w działalności Towarzystwa;

3) płacenia składki członkowskiej.

\section{Art. 11}

1. Członkostwo w Towarzystwie ustaje:

1) z chwilą wpłynięcia do zarządu oświadczenia członka o wystąpieniu z Towarzystwa;

2) z chwilą stwierdzenia przez właściwą władzę kościelną popełnienia kanonicznego przestępstwa przeciwko wierze lub jedności Kościoła albo gdy podlega ekskomunice (kan. 316 § 2 $\mathrm{KPK}$;

3) w przypadku stwierdzonego przez zarząd bezwzględną większością głosów rażącego naruszenia statutu przez członka;

4) za działalność na szkodę Towarzystwa stwierdzoną przez zarząd bezwzględną większością głosów. 
2. W przypadku złożenia odwołania od decyzji zarządu, o którym mowa wart.15, dochwilirozstrzygnięcia członekTowarzystwajestzawieszony.

Art. 12

1. Członkiem wspierającym może być katolik, który jednocześnie:

1) nie ubiega się o członkostwo zwyczajne;

2) identyfikuje się z celami Towarzystwa;

3) wspiera działalność Towarzystwa.

2. O przyjęciu albo usunięciu członka wspierającego decyduje zarząd bezwzględną większością głosów.

Art. 13

Członek wspierający ma prawo do udziału w spotkaniach naukowych organizowanych przez Towarzystwo oraz do korzystania z Biblioteki Towarzystwa na tych samych zasadach co członkowie zwyczajni.

Art. 14

1. Członkiem honorowym może zostać osoba wybitnie zasłużona dla Towarzystwa lub dla rozwoju nauk teologicznych.

2. Członków honorowych mianuje lub usuwa walne zebranie uchwałą podjętą zwykłą większością głosów na wniosek zarządu podjęty zwykłą większością głosów.

\section{Art. 15}

Od decyzji zarządu dotyczących członkostwa przysługuje odwołanie do walnego zebrania. Pierwsze walne zebranie po złożeniu odwołania rozstrzyga odwołanie zwykłą większością głosów.

\section{Ustrój Towarzystwa}

\section{Art. 16}

Władzami Towarzystwa są:

1) walne zebranie;

2) zarząd;

3) komisja rewizyjna; 
4) sąd polubowny.

\section{Art. 17}

1. Walne zebranie jest władzą najwyższą Towarzystwa.

2. Walne zebranie zbiera się nie później niż w pierwszym kwartale każdego roku.

3. W walnym zebraniu biorą udział członkowie zwyczajni, wspierający i honorowi.

4. Uchwały walnego zebrania zapadają większością głosów członków zwyczajnych.

5. Członkowie wspierający i członkowie honorowi uczestniczą w zebraniu z głosem doradczym.

Art. 18

Do zadań walnego zebrania należą w szczególności:

1) przyjmowanie sprawozdania zarządu (prezesa, skarbnika i kierownika Sekcji Wydawniczej) oraz komisji rewizyjnej;

2) uchwalanie wewnętrznych aktów normatywnych Towarzystwa;

3) udzielanie zarządowi absolutorium z działalności i administracji majątkiem;

4) określenie kierunków pracy Towarzystwa;

5) podejmowanie decyzji o sprawach przedstawionych przez zarząd;

6) wybieranie zarządu, komisji rewizyjnej i sądu polubownego;

7) uzupełnianie składu zarządu, komisji rewizyjnej i sądu polubownego;

8) nadzwyczajny zarząd majątkiem Towarzystwa, w tym sposób zaciągania zobowiązań majątkowych lub powoływanie fundacji.

\section{Art. 19}

Nadzwyczajne walne zebranie zwołuje zarząd z własnej inicjatywy, na wniosek komisji rewizyjnej lub na żądanie przynajmniej jednej trzeciej ogólnej liczby członków zwyczajnych Towarzystwa.

\section{Art. 20}

Przebieg walnego zebrania jest regulowany regulaminem uchwalonym przez walne zebranie. 
Art. 21

Wybór władz Towarzystwa jest regulowany regulaminem uchwalonym przez walne zebranie.

Art. 22

1. Kadencja członków zarządu, komisji rewizyjnej i sądu polubownego trwa trzy lata od daty ich wyboru.

2. Liczba kadencji nie jest ograniczona.

3. Członkowie pełnią obowiązki od czasu upływu kadencji do nowych wyborów, a w przypadku członków zarządu - do zatwierdzenia przez Konferencję Episkopatu Polski.

4. Wakujące stanowisko w komisji rewizyjnej lub sądzie polubownym uzupełnia się podczas walnego zebrania.

5. Wakujące stanowisko w zarządzie przejmuje prezes. W razie wakatu na stanowisku prezesa jego obowiązki przejmuje wiceprezes.

Art. 23

1. Władzą wykonawczą Towarzystwa jest zarząd, którego wybór zatwierdza Konferencja Episkopatu Polski.

2. Zarząd składa się z prezesa, wiceprezesa, sekretarza, skarbnika, bibliotekarza i kierownika Sekcji Wydawniczej.

3. Członkiem zarządu nie może być osoba skazana prawomocnym wyrokiem za przestępstwo umyślne ścigane z oskarżenia publicznego lub przestępstwo skarbowe.

\section{Art. 24}

Do zadań zarządu należy w szczególności:

1) zwoływanie walnego zebrania i przygotowanie jego przebiegu;

2) wykonywanie uchwał walnego zebrania;

3) określanie wysokości składki członkowskiej;

4) administrowanie majątkiem w ramach zwykłego zarządu;

5) kierowanie działalnością gospodarczą, jeżeli taka jest prowadzona;

6) przyznawanie nagród naukowych Towarzystwa;

7) powoływanie sekcji specjalistycznych i oddziałów po uzyskaniu pisemnego zezwolenia biskupa właściwego diecezjalnego; 
8) organizowanie spotkań naukowych;

9) obsadzanie stanowisk redaktorów naczelnych czasopism wydawanych przez Towarzystwo;

10) przyjmowanie, wykluczanie i deklarowanie ustania członkostwa członków Towarzystwa;

11) powoływanie kierowników sekcji specjalistycznych i oddziałów;

12) określanie zakresu działalności sekcji specjalistycznych i oddziałów;

13) składanie Konferencji Episkopatu Polski raz w roku pisemnego sprawozdania z działalności Towarzystwa, w tym z działalności finansowej (kan. 319 KPK).

Art. 25

Tworzenie sekcji specjalistycznych i oddziałów, ich znoszenie, a także powoływanie i odwoływanie kierowników sekcji specjalistycznych i oddziałów reguluje regulamin uchwalony przez walne zebranie.

Art. 26

Towarzystwo reprezentuje na zewnątrz prezes albo z upoważnienia prezesa wiceprezes lub inny członek zarządu, z zastrzeżeniem art. 34 pkt 1.

Art. 27

Uchwały zarządu zapadają bezwzględną większością głosów przy obecności przynajmniej połowy jego członków, a w razie równego rozłożenia głosów rozstrzyga głos prezesa.

Art. 28

1. Zebrania zarządu odbywają się przynajmniej cztery razy w roku.

2. Zebrania zarządu są protokołowane. Protokół zatwierdza prezes albo wiceprezes i sekretarz.

Art. 29

Członek zarządu ma obowiązek:

1) uczestniczenia w zebraniach zarządu;

2) wykonywania czynności określonych prawem wewnętrznym Towarzystwa lub zleconych przez prezesa. 
Art. 30

1. Prezes kieruje całokształtem działalności Towarzystwa, a w szczególności:

1) zwołuje zebrania zarządu i przewodniczy im;

2) troszczy się o majątek Towarzystwa;

3) zawiesza w czynnościach członka zarządu w wypadku działania na szkodę Towarzystwa;

4) ma prawo udziału w posiedzeniach komisji rewizyjnej;

5) ma prawo zawieszania uchwał Sekcji Wydawniczej, sekcji specjalistycznych i oddziałów.

2. O podtrzymaniu albo uchyleniu zawieszenia przez prezesa zarówno członków zarządu, jak i uchwał sekcji specjalistycznych oraz oddziałów decyduje w głosowaniu zarząd na najbliższym zebraniu.

Art. 31

Sekretarz:

1) prowadzi kancelarię zarządu;

2) protokołuje posiedzenia zarządu;

3) kontrasygnuje pisma prezesa.

Art. 32

Skarbnik:

1) prowadzi kasę i obsługuje rachunki bankowe Towarzystwa;

2) prowadzi księgi rachunkowe lub inną dokumentację finansową Towarzystwa.

Art. 33

Bibliotekarz:

1) prowadzi bibliotekę Towarzystwa;

2) upowszechnia czytelnictwo wśród członków Towarzystwa.

Art. 34

Kierownik Sekcji Wydawniczej odpowiada za prowadzenie działalności wydawniczej przez Towarzystwo, a w szczególności: 
1) reprezentuje Sekcję Wydawniczą na zewnątrz i wobec władz Towarzystwa;

2) zarządza majątkiem Sekcji Wydawniczej i ma prawo zaciągania zobowiązań dotyczących jej majątku;

3) opracowuje lub realizuje plany wydawnicze;

4) odpowiada za sprzedaż i udostępnianie publikacji wydawanych przez Towarzystwo.

Art. 35

1. Zasady działania Sekcji Wydawniczej określa regulamin Sekcji Wydawniczej.

2. Sekcja Wydawnicza prowadzi Wydawnictwo UNUM.

Art. 36

1. Komisja rewizyjna składa się z przewodniczącego i dwóch członków.

2. Przewodniczący i członkowie komisji rewizyjnej:

1) nie mogą być członkami zarządu ani pozostawać z nimi w związku małżeńskim, we wspólnym pożyciu, w stosunku pokrewieństwa, powinowactwa lub podległości służbowej;

2) nie byli skazani prawomocnym wyrokiem za przestępstwo umyślne ścigane z oskarżenia publicznego lub przestępstwo skarbowe;

3) mogą otrzymywać z tytułu pełnienia funkcji zwrot uzasadnionych kosztów lub wynagrodzenie w wysokości nie wyższej niż przeciętne miesięczne wynagrodzenie w sektorze przedsiębiorstw ogłoszone przez Prezesa Głównego Urzędu Statystycznego za rok poprzedni.

Art. 37

Komisja rewizyjna:

1) nie podlega zarządowi w zakresie wykonywania kontroli wewnętrznej lub nadzoru;

2) sprawuje kontrolę nad działalnością zarządu oraz Sekcji Wydawniczej;

3) ma prawo żądać od zarządu zwołania walnego zebrania lub zebrania zarządu; 
4) składa ze swych czynności sprawozdania na walnym zebraniu;

5) stawia wniosek na walnym zebraniu o absolutorium dla zarządu;

6) może wyznaczyć swojego delegata na zebrania zarządu lub sekcji specjalistycznych.

Art. 38

W razie stwierdzenia działalności na szkodę Towarzystwa ze strony członka zarządu komisja rewizyjna ma prawo żądać od prezesa zawieszenia tego członka w czynnościach.

Art. 39

W przypadku, gdy prezes działa na wielką szkodę Towarzystwa, komisja rewizyjna zwołuje walne zebranie.

Art. 40

Przewodniczący komisji rewizyjnej w szczególności:

1) zwołuje i przewodniczy zebraniom komisji;

2) inicjuje inne działania komisji.

Art. 41

1. Sąd polubowny Towarzystwa składa się z przewodniczącego i dwóch członków wybranych przez walne zebranie.

2. Sąd polubowny Towarzystwa rozstrzyga spory między członkami w zakresie działania Towarzystwa.

\section{Majątek Towarzystwa}

Art. 42

Majątek Towarzystwa składa się z gotówki, wierzytelności, ruchomości i nieruchomości.

Art. 43

Majątek Towarzystwa powstaje ze składek członkowskich, darowizn, zapisów, dochodów niestałych oraz własnej działalności gospodarczej, jeżeli jest prowadzona. 
Art. 44

Zabrania się:

1) udzielania pożyczek lub zabezpieczania zobowiązań majątkiem Towarzystwa w stosunku do jej członków, członków organów lub pracowników oraz osób, z którymi członkowie, członkowie organów oraz pracownicy organizacji pozostają w związku małżeńskim, we wspólnym pożyciu albo w stosunku pokrewieństwa lub powinowactwa w linii prostej, pokrewieństwa lub powinowactwa w linii bocznej do drugiego stopnia albo są związani z tytułu przysposobienia, opieki lub kurateli, zwanych dalej osobami bliskimi;

2) przekazywania ich majątku na rzecz ich członków, członków organów lub pracowników oraz ich osób bliskich, na zasadach innych niż w stosunku do osób trzecich, w szczególności, jeżeli przekazanie to następuje bezpłatnie lub na preferencyjnych warunkach;

3) wykorzystywania majątku na rzecz członków, członków organów lub pracowników oraz ich osób bliskich na zasadach innych niż w stosunku do osób trzecich, chyba że to wykorzystanie bezpośrednio wynika z celu statutowego;

4) zakupu towarów lub usług od podmiotów, w których uczestniczą członkowie organizacji, członkowie jej organów lub pracownicy oraz ich osób bliskich, na zasadach innych niż w stosunku do osób trzecich lub po cenach wyższych niż rynkowe.

\section{Przepisy końcowe}

Art. 45

1. Statut lub zmianę statutu uchwala walne zebranie kwalifikowaną większością 2/3 głosów.

2. Statut Towarzystwa oraz jego zmiany wymagają zaaprobowania przez Konferencję Episkopatu Polski.

\section{Art. 46}

1. Towarzystwo może być rozwiązane przez Konferencję Episkopatu Polski na wniosek walnego zebrania lub z własnej inicjatywy. Walne zebranie podejmuje uchwałę w sprawie rozwiązania Towarzystwa 
kwalifikowaną większością 2/3 głosów członków Towarzystwa obecnych na zebraniu.

2. Likwidatora Towarzystwa wskazuje Konferencja Episkopatu Polski.

3. O przeznaczeniu majątku pozostałego po likwidacji Towarzystwa decyduje Konferencja Episkopatu Polski.

Art. 47

Statut wchodzi w życie z dniem zaaprobowania przez Konferencję Episkopatu Polski.

Statut niniejszy przyjęty przez walne zebranie Polskiego Towarzystwa Teologicznego uchwata z dnia 26 lutego 2019 r., zatwierdzony został przez Konferencję Episkopatu Polski na mocy uchwały nr 4/382/2019 $z$ dnia 12 marca $2019 r$.

+ Stanisław Gadecki Arcybiskup Metropolita Poznański Przewodniczacy KEP

† Artur G. Miziński Sekretarz Generalny KEP 